\title{
Quantification of fairness bias by a Fairness-Equity Model
}

\author{
David Nicoladie Tam \\ From Twentieth Annual Computational Neuroscience Meeting: CNS*2011 \\ Stockholm, Sweden. 23-28 July 2011
}

We have developed a computational model that quantifies fairness objectively based on equity/disparity between the shares by two individuals. This FairnessEquity Model [1] represents the relationship between fairness perception intensity and the disparity (or equity) between two individuals graphically. Fairness bias is represented by what is considered as equitable between the shares. Absolute equity represents equal shares, while relative equity represents unequal shares. Tolerance to inequity is represented by the unequal share, yet considered as fair. This represents fairness bias, in which inequitable share is tolerated as fair. This tolerance for inequity can be represented graphically by the fairness-equity graph by shifting the fairness-curve horizontally. Sensitivity to fairness or unfairness can also be represented by the increasing the slope of the fairnesscurve. Fairness perception is also hypothesized by the proportionality relationship to the equity/disparity measures.

Confirmation of this proportional hypothesis is provided by using the Ultimatum Game (UG) with human subjects. The results show that fairness perception is proportional to the equity/disparity signal. The fairness biases are also quantified the shifting of the fairnesscurve relative to the acceptance and rejection decision in the UG experiment. It further reveals the objectivity of fairness perception to equitable share compared to the subjectivity of fairness perception to inequitable share.

Published: 18 July 2011

Correspondence: dtam@unt.edu

Department of Biological Sciences, University of North Texas, Denton, TX 76203, USA

C Biomed Central

(C) 2011 Tam; licensee BioMed Central Ltd. This is an open access article distributed under the terms of the Creative Commons Attribution License (http://creativecommons.org/licenses/by/2.0), which permits unrestricted use, distribution, and reproduction in any medium, provided the original work is properly cited.

\section{Reference}

1. Tam DN: Objectivity in subjective perception of fairness: relativity in proportionality relationship with equity by switching frame-of-reference - a fairness-equity model., (submitted).

doi:10.1186/1471-2202-12-S1-P327

Cite this article as: Tam: Quantification of fairness bias by a FairnessEquity Model. BMC Neuroscience 2011 12(Suppl 1):P327.

Submit your next manuscript to BioMed Central and take full advantage of:

- Convenient online submission

- Thorough peer review

- No space constraints or color figure charges

- Immediate publication on acceptance

- Inclusion in PubMed, CAS, Scopus and Google Scholar

- Research which is freely available for redistribution 